Plant Tissue Cult. \& Biotech. 23(1): 39-47, 2013 (June)

$\overline{\text { PTC\&B }}$

\title{
In Vitro Mass Propagation of Ornamentally and Medicinally Important Coelogyne flaccida Lindl. through Pseudobulb Segments
}

\section{Saranjeet Kaur ${ }^{1}$ and K.K. Bhutani}

Plant Tissue Culture and Biotechnology Laboratory, Department of Natural Products, National Institute of Pharmaceutical Education and Research, Sector-67, Mohali- 160 062, Punjab, India

Key words: Mass propagation, Coelogyne flaccida, Epiphyte orchid, Pseudobulbs

\begin{abstract}
Regeneration competence of pseudobulb segments of Coelogyne flaccida, procured from in vitro grown cultures, was assessed in MS and Mitra (M) medium alone and in combinations with BA $(4.44 \mu \mathrm{M}), \mathrm{Kn}(5.65 \mu \mathrm{M}), \mathrm{NAA}(5.37 \mu \mathrm{M})$, and coconut water (CW 10\%). Juvenility of the tissues, chemical stimulus, and position of the explants (apical/basal) were the key factors in initiating the response. The explants from pseudobulbs $(>0.8 \mathrm{~cm}$ in length) did not regenerate whereas those from younger ones $(<0.8 \mathrm{~cm}$ in length) regenerated. The response frequency and time taken for the development of plantlets also varied with the growth stimulus. Maximum number of shoots was obtained from the basal segments (nodal and extra-nodal regions), cultured in MS + NAA/NAA + BA forming $10.25 \pm 0.50$ and 10.00 shoots, respectively. The apical segments formed shoots only from apical meristem. The shoots rooted in the same nutrient medium and formed plantlets.
\end{abstract}

\section{Introduction}

Coelogyne flaccida Lindl. is a cool growing, evergreen epiphytic orchid species. It is one of the prettiest of the coelogynes possessing heavily scented flowers. The species bloom simultaneously from spring to early summer months. Biogeographically, it extends from India to China in the tropical to sub-tropical Himalayas at an altitude of $900-1400 \mathrm{~m}$. Besides being horticulturally significant, the species is medicinally important as well. Biologically active compounds (Phenenthrene derivatives) such as flaccidin and oxaloflaccidin are

${ }^{1}$ Author for correspondence: <sarana_123@rediffmail.com>. 
isolated from whole plants of this species (Majumdar and Maiti 1989). Pharmacological studies have shown that the species possess an anti-bacterial activity and the paste of its pseudobulbs is applied to the forehead to treat headache and their juice is also administered orally to treat indigestion (Pyakurel and Gurung 2008). C. flaccida is faced with habitat destruction pressures which far exceeds its natural regeneration. As a result the species has become threatened in its natural habitats. The genus Coelogyne is included in Appendix II of the Convention on International Trade in Endangered Species of Wild Fauna and Flora (CITES 2012). Hence, it is strongly emphasized to conserve, propagate and multiply the species, through tissue culture techniques and to popularize the species among amateurs, nurserymen and professionals to cultivate the species thus saving its wild populations from getting extinct.

In clonal mass propagation, it is immensely important to maintain genetic uniformity of in vitro raised progenies. In outbreeding taxa like orchids, seed raised progenies are extremely heterozygous and to retain genetic integrity of the regenerants, appropriate in vitro propagation protocols are required. The utility of pseudobulb segments, as an effective alternative to shoot meristem for micropropagating orchids is a successful approach in this direction as this method provides opportunities to produce a large number of true-to-type plantlets of interest. Orchids are propagated in vitro by using various explants such as shoot meristem, leaves, roots, protocorms etc. obtained from axenic cultures but the regenerative potential of pseudobulbs as explants has been less explored as compared to the other explants (Morel 1960, 1970, Stewart and Button 1976, Vajrabhaya 1978, Shimasaki and Uemoto 1987, Arditti and Ernst 1993, George and Ravishankar 1997, Vij and Kaur 1998, Kanjilal et al. 1999, Pyati et al. 2002, Decruse et al. 2003, Basker and Narmatha 2006, Martin 2007, Janarthanam and Seshadri 2008, Medina et al. 2009, Sungkum and Deb 2009, Sunitibala and Kishor 2009, Hong et al. 2010, Mata-Rosas et al. 2010, Kaur and Bhutani 2010, Rajkarnikar 2011, Pant and Thapa 2012). Therefore, an attempt was made to establish an efficient regeneration system by using pseudobulbs as explants for C. flaccida in particular checking the (i) influence of maturity level of pseudobulbs on regeneration potential, (ii) suitable culture medium, and the effect of growth regulators individually and in combination on regeneration of the explants and their successive development into plantlets (iii) induction potential of the apical and basal segments. There is no report on the development of in vitro methodology for mass propagation of $C$. flaccida using different explants. In this first ever report, an efficient and reproducible one step protocol for the development of plantlets from in vitro derived pseudobulb segments is reported. 


\section{Materials and Methods}

Coelogyne flaccida plants were collected from a commercial grower of Darjeeling district, West Bengal, India (latitude range: $26^{\circ} 31^{\prime}-27^{\circ} 13^{\prime} \mathrm{N}$; longitude range: $87^{\circ} 59^{\prime}-88^{\circ} 53^{\prime}$ E). The plants were collected and replanted in the pots (diam 27.5 $\mathrm{cm} \times 22.4 \mathrm{~cm}$ ) containing epiphytic substrate such as charcoal pieces, brick pieces, and bark pieces $(1: 1: 1)$. The sphagnum moss covered the top surface of potting mix to retain moisture. The plants were maintained in the greenhouse under natural light conditions with $70 \%$ relative humidity and $25 / 20^{\circ} \mathrm{C}$ day/night temperature.

The explants (pseudobulbs; $<0.8 \mathrm{~cm}$ long) were procured from 36 weeks old aseptic cultures, raised from in vitro asymbiotic seed germination technique. Inside a laminar air-flow cabinet, under aseptic conditions the seedlings were removed from the culture vessels and their leaves and roots were severed off without making any injury to the donor pseudobulbs. These were segmented into two equal halves i.e. apical and basal segments and inoculated on MS (Himedia, Mumbai, India) and M medium (Mitra et al. 1976, Hi-media, Mumbai, India) and their combinations with BA- $4.44 \mu \mathrm{M} / \mathrm{K}-4.65 \mu \mathrm{M} / \mathrm{NAA}-5.37 \mu \mathrm{M}$ and CW $10 \%(\mathrm{v} / \mathrm{v})$. Coconut water was procured from fresh green coconuts purchased from the market. They were peeled off and the coconut water was drawn off, collected, filtered through a sieve and used as such in the medium. The $\mathrm{pH}$ of the medium was adjusted to 5.7 after adding the growth regulators and organic growth supplements. The media were gelled with $0.8 \%$ (MS) and $0.9 \%(\mathrm{M})$ agar powder (Hi-Media, Mumbai, India) and dispensed in test tubes $(25 \mathrm{~mm} \times 150 \mathrm{~mm})$. The media were autoclaved at $121^{\circ} \mathrm{C}$ at pressure of $1.06 \mathrm{~kg}$ $\mathrm{cm}^{-2}$ for $15 \mathrm{~min}$. Autoclaved medium was kept at $37^{\circ} \mathrm{C}$ to check any further contamination.

The inoculations were done under aseptic conditions in a laminar air-flow cabinet. The cultures vessels with inoculated explants were incubated in a culture room at $25 \pm 2{ }^{\circ} \mathrm{C}$ under a 12/12 hrs light-dark photoperiod at $40 \mu \mathrm{mol} /$ $\mathrm{m}^{2} / \mathrm{s}$ light intensity provided by white fluorescent tubes (Fluorescent tubes, Philips India Ltd., Mumbai, India). To check the reproducibility of the protocol, the experiment was repeated twice. Sub-culturings were done as and when required.

The experiment was designed following CRD. The results were expressed as means $\pm \mathrm{Sd}$ of four replicates. The cultures were observed regularly under binocular microscope (Olympus SZ X10, Japan) and data recorded accordingly. Data were subjected to analysis of variance (one way ANOVA) and Tukey's multiple range test using SPSS version 16.0 (SPSS Inc. Chicago, US). 


\section{Results and Discussion}

The regeneration potential of Coelogyne flaccida pseudobulb segments was positively tested in MS and M medium and their combinations with growth adjuncts. Culture initiation was markedly influenced by physiological age (in terms of juvenility) of donor tissues besides chemical stimulus in the nutrient pool. Such phenomenon is on records in orchids (Arditti and Ernst 1993, Vajrabhaya 1978, Vij and Kaur 1998, Basker and Narmatha 2006, Janarthanam and Seshadri 2008, Kaur and Bhutani 2010). Morphogenetic potential of juvenile tissues (less differentiated) depends upon biochemical and physiological state of the donor tissues and division activity of the cells is also influenced by the condition of the cell walls i.e., those cells divide more actively who has less rigid cell walls according to Misra and Bhatnagar (1995). Presently, the pseudobulb explants from relatively older ones $(>0.8 \mathrm{~cm}$ in length) remained recalcitrant to regeneration whereas those representing relatively younger ones $(<0.8$ in length) responded positively in the nutrient mix (Tables 1,2 ). In the present experiment, the regeneration response was better in MS than $M$ medium in terms of percentage of responding explants, mean number of induced regenerants, their successive multiplication and development into plantlets suggesting, thereby, more complex nutritional requirements of the explants of $C$. flaccida to induce more number of meristemoids. MS is more concentrated than M medium in mineral salt composition. The comparison of the mineral composition of both media clearly points out that the total nitrogen content is higher in MS medium than $\mathrm{M}$ medium. Meagre response in the explants in $\mathrm{M}$ medium could have occurred due to the less nitrogen $(\mathrm{N})$ in the medium composition. Literature survey indicates that an appropriate $\mathrm{NO}_{3}^{-}: \mathrm{NH}_{4}{ }^{+}$influences morphogenesis and embryogenesis in the explants (Ramage and Williams 2002). The different $\mathrm{NO}_{3}^{-}$: $\mathrm{NH}_{4}{ }^{+}$levels effect indirectly to $\mathrm{pH}$ changes, which control cation absorption and eventually morphogenesis (Cousson and Tran Thanh Van 1993). Ions such as $\mathrm{Ca}_{2}{ }^{+}, \mathrm{Mg}_{2}{ }^{+}, \mathrm{K}^{+},\left(\mathrm{SO}_{4}\right)_{2}-\mathrm{H}_{2} \mathrm{PO}_{4}{ }^{-}, \mathrm{Cl}^{-}$are also correlated with initiation of the morphogenetic activity in the tissues (Benson 2000, Pinto et al. 2008). In the present study, it is clear that higher content of nitrogenous elements and appropriate proportion of $\mathrm{NO}_{3}{ }^{-}$and $\mathrm{NH}_{4}{ }^{+}$ions in the medium favoured higher regeneration percentage in C. flaccida pseudobulb segments in MS. The results are in accord with similar earlier findings in Tainia latifolia where also MS proved efficient over other media used to initiate and regenerate the cultures (Sungkum and Deb 2009).

Addition of growth regulators in the basal medium induced multiple shoot buds in the explants in selective combinations. The average number of regenerants varied with the type of growth regulator in the nutrient pool. In the 
MS basal medium, $18.75 \pm 2.93 \%$ explants showed signs of regeneration after 5.17 \pm 0.05 weeks of culture (Table 1) whereas in M medium, only $6.25 \pm 0.12 \%$ explants responded to regeneration (Table 2). In MS, amongst all the growth regulators, a significant number of shoots were obtained in a treatment with NAA, which remained highly productive in inducing multiple adventive meristematic loci at the axillary and extra-axillary meristem and as well as at the

Table 1. In vitro regeneration response of Coelogyne flaccida pseudobulb segments in MS and its combinations with growth adjuncts as treatments

\begin{tabular}{lllll}
\hline Treatment & $\begin{array}{l}\text { Initiation of } \\
\text { response (weeks) }\end{array}$ & $\begin{array}{l}\text { Regeneration } \\
\text { response }(\%)\end{array}$ & Shoots/explant & $\begin{array}{l}\text { Development of } \\
\text { plantlets (weeks) }\end{array}$ \\
\hline MS $_{\text {(control) }}$ & $5.17 \pm 0.05^{\text {bcdeg }}$ & $18.75 \pm 2.93^{\mathrm{de}}$ & $1.00 \pm 0.00^{\mathrm{de}}$ & $12.07 \pm 0.09^{\mathrm{de}}$ \\
$\mathrm{BA}$ & $4.17 \pm 0.05^{\mathrm{acdefg}}$ & $25.00 \pm 0.28^{\mathrm{de}}$ & $2.92 \pm 0.29^{\mathrm{acdefg}}$ & $11.75 \pm 0.59^{\mathrm{de}}$ \\
$\mathrm{K}$ & $5.42 \pm 0.05^{\mathrm{abde}}$ & $18.75 \pm 0.23^{\mathrm{de}}$ & $0.75 \pm 0.50^{\mathrm{bde}}$ & $12.50 \pm 0.57^{\mathrm{de}}$ \\
$\mathrm{NAA}$ & $3.00 \pm 0.00^{\mathrm{abcfg}}$ & $87.50 \pm 0.25^{\mathrm{abcg}}$ & $10.25 \pm 0.50^{\mathrm{abcfg}}$ & $8.07 \pm 0.09^{\mathrm{abcefg}}$ \\
$\mathrm{NAA}+\mathrm{BA}$ & $3.07 \pm 0.50^{\mathrm{abcfg}}$ & $87.25 \pm 0.12^{\mathrm{abcg}}$ & $10.00 \pm 0.00^{\mathrm{abcfg}}$ & $9.12 \pm 0.15^{\mathrm{abcdfg}}$ \\
$\mathrm{NAA}+\mathrm{K}$ & $5.22 \pm 0.20^{\mathrm{bdeg}}$ & $43.75 \pm 1.25^{\mathrm{acdeg}}$ & $1.25 \pm 0.95^{\mathrm{bde}}$ & $12.15 \pm 0.12^{\mathrm{de}}$ \\
$\mathrm{CW}_{(10 \%)}$ & $5.45 \pm 0.57^{\mathrm{abdef}}$ & $6.25 \pm 0.12^{\mathrm{de}}$ & $0.75 \pm 0.95^{\mathrm{bde}}$ & $12.35 \pm 0.2^{\mathrm{de}}$ \\
\hline
\end{tabular}

BA - $4.44 \mu \mathrm{M}, \mathrm{K}-5.65 \mu \mathrm{M}, \mathrm{NAA}-5.37 \mu \mathrm{M}, \mathrm{CW}$ - coconut water - (\% v/v). Values in a column with similar superscripts are not significantly different at $\mathrm{p} \leq 0.05$ according to Tukey's test.

Table 2. In vitro regeneration response of Coelogyne flaccida pseudobulb segments in $M$ medium and its combinations with growth adjuncts as treatments.

\begin{tabular}{lllll}
\hline Treatment & $\begin{array}{l}\text { Initiation of } \\
\text { response (weeks) }\end{array}$ & $\begin{array}{l}\text { Regeneration } \\
\text { response }(\%)\end{array}$ & $\begin{array}{l}\text { Shoots/ } \\
\text { explant }\end{array}$ & $\begin{array}{l}\text { Development of } \\
\text { plantlets (weeks) }\end{array}$ \\
\hline $\mathrm{M}_{\text {(control) }}$ & $6.15 \pm 0.05^{\mathrm{de}}$ & $6.25 \pm 0.12^{\mathrm{de}}$ & $0.50 \pm 0.50^{\mathrm{d}}$ & $17.05 \pm 0.10^{\text {bdef }}$ \\
$\mathrm{BA}$ & $5.95 \pm 0.32^{\mathrm{de}}$ & $12.50 \pm 1.44^{\mathrm{de}}$ & $0.75 \pm 0.09^{\mathrm{cfg}}$ & $16.05 \pm 0.10^{\text {ade }}$ \\
$\mathrm{K}$ & $6.32 \pm 0.15^{\mathrm{de}}$ & $6.25 \pm 0.12^{\mathrm{de}}$ & $0.25 \pm 0.05^{\mathrm{bde}}$ & $16.60 \pm 0.49^{\mathrm{def}}$ \\
$\mathrm{NAA}$ & $5.00 \pm 0.28^{\mathrm{abcfg}}$ & $25.00 \pm 0.28^{\mathrm{abcfg}}$ & $1.00 \pm 0.11^{\mathrm{acfg}}$ & $14.82 \pm 0.41^{\mathrm{abcg}}$ \\
$\mathrm{NAA}+\mathrm{BA}$ & $5.22 \pm 0.17^{\mathrm{abcfg}}$ & $25.00 \pm 0.20^{\mathrm{abcfg}}$ & $0.75 \pm 0.09^{\mathrm{cfg}}$ & $15.20 \pm 0.21^{\mathrm{abcg}}$ \\
$\mathrm{NAA}+\mathrm{K}$ & $6.30 \pm 0.11^{\mathrm{de}}$ & $12.50 \pm 0.25^{\mathrm{de}}$ & $0.25 \pm 0.05^{\text {bde }}$ & $15.30 \pm 0.11^{\text {acg }}$ \\
$\mathrm{CW}_{(10 \%)}$ & $6.37 \pm 0.14^{\mathrm{de}}$ & $6.25 \pm 0.12^{\mathrm{de}}$ & $0.25 \pm 0.17^{\text {bde }}$ & $16.60 \pm 0.03^{\text {def }}$ \\
\hline
\end{tabular}

BA - $4.44 \mu \mathrm{M}, \mathrm{K}-5.65 \mu \mathrm{M}, \mathrm{NAA}-5.37 \mu \mathrm{M}, \mathrm{CW}$ - coconut water - (\% v/v). Values in a column with similar superscripts are not significantly different at $\mathrm{p} \leq 0.05$ according to Tukey's test.

inter-nodal regions (i.e., cut surfaces) by invocation of shootbuds in $87.50 \pm 0.25 \%$ explants. These multiple adventive meristematic loci underwent organogenesis and transformed into shoots. More number of shoots was induced in the basal segments than apical ones (Fig. 1a). With passage of time, these shoot buds grew and completely covered the explants as evident in Fig. 1b. As many as $10.25 \pm$ 0.50 shoots were obtained after 3 weeks of culture, respectively. These 
regenerated shoots later expanded their leaves and developed tufts of hairs at the base of shoots prior to the induction of rhizogenesis in the cultures (Fig. 1c). Plantlets were formed after $8.07 \pm 0.09$ weeks of culture.
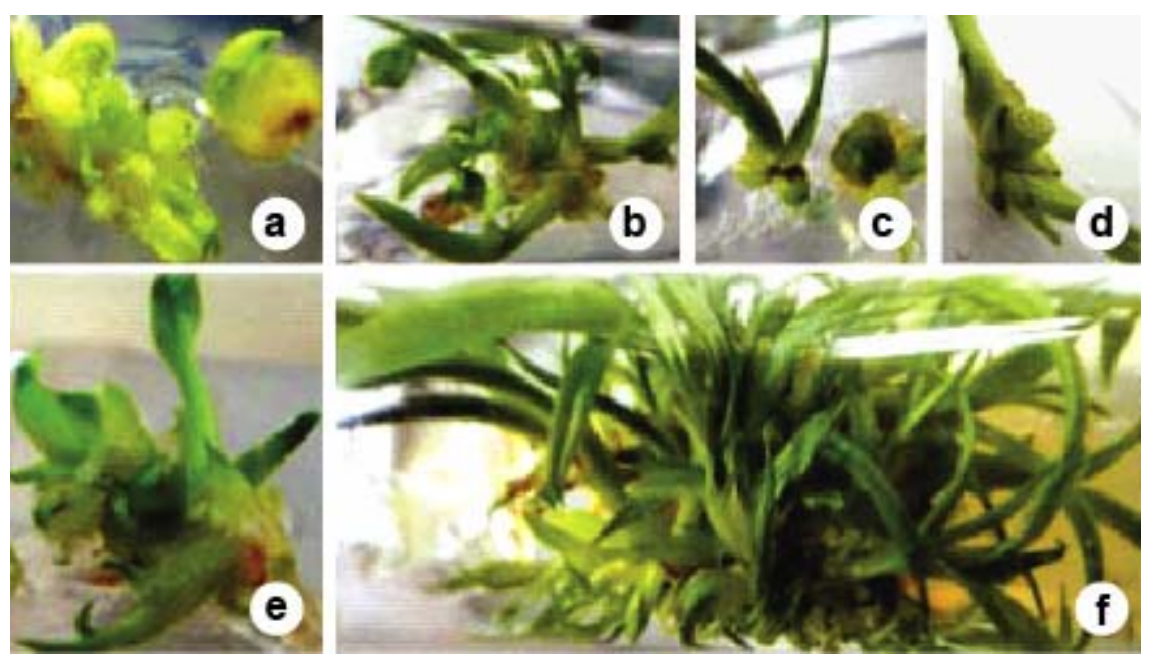

Fig. 1. In vitro regeneration response of pseudobulb segments of Coelogyne flaccida in MS and its combinations with growth adjuncts. a. Induction of more number of shoots in the basal segments in NAA enriched medium. b. Growth of shoots completely covering the explants in NAA supplemented medium. c. Regenerated shoots expanded their leaves and developed tufts of hairs at the base of shoots in NAA supplemented medium. d. Apical segment showing initiation of shoot buds from apical meristem zone in BA treated cultures. e. Rhizogenesis in the shoots while still attached to the segments in the same medium BA enriched medium. $\mathrm{f}$. Dense growth of plantlets in BA + NAA supplemented medium.

NAA with Kn was not found very productive, and an individual treatment with CW $(10 \%)$ and cytokinins also lowered the regeneration response in the explants. In BA treated explants, only $2.92 \pm 0.29$ shoot buds were formed from axillary bud meristem after 7 weeks. The shoots which formed earlier from basal segments developed faster into plantlets than those from apical segments (Fig. 1d). A combination of NAA with BA was also highly productive, similar to a treatment with NAA in the medium, in eliciting 10 shoot buds in the explants (Fig. 1e). Reports, till now, indicate similar synergistic action of the combination of auxin and cytokinin in inducing more regeneration loci in the explants in Dendrobium moschatum (Kanjilal et al. 1999), Dendrobium candidum (Shiau et al. 2005), Coelogyne cristata (Basker and Narmatha 2006), Dendrobium transparens (Sunitibala and Kishor 2009), Malaxis acuminata (Kaur and Bhutani 2010), Zygopetalum mackayi (Hong et al. 2010), Lycaste aromatica (Mata-Rosas et al. 2010), Dendrobium fimbriatum (Rajkarnikar 2011), in Dendrobium primulinum (Pant and Thapa 2012) but in present cultures, an individual treatment with NAA also proved equally and highly effective to that of combinations of auxin and 
cytokinin, in eliciting maximum regeneration in the explants. During growth and maintenance of the cultures, it was also spotted that dense cultures repressed the development of pseudobulbs in the plantlets. Morphologically, the plantlets appeared thin and elongated (Fig. 1f). Therefore, for better growth the individual plantlets were subcultured in NAA/NAA + BA supplemented medium. The plantlets grew well in the culture vessels.

In the segments, the shoot development was observed to be a process of direct organogenesis, invariably in all the cultures, irrespective of the media treatment at the nodal (extra axillary) and at the cut surfaces of the explant. Reports highlight the importance of modifying the endogenous growth hormones ratio (auxin/cytokinin) by exogenous growth regulators application in initiating new shoots by the activation of resident apical and lateral buds into shoots or induction of multiple shoots from these meristematic areas (George 1993). In this study, the responding explants irrespective of the plant growth regulator treatments invariably followed organogenetic pathway of regeneration i.e. shoot bud formation whereas according to Terzi and Lo Schiavo (1990) the type of regeneration pathway which is to be followed by regenerants strongly depends upon the type and concentration of plant growth regulators to which they are subjected. Shoot formation was significantly more discernible in the basal segments than the apical ones. The regeneration in the apical segments was always observed via induction of resident (apical) meristem and produced a fewer plantlets. In the basal segments, more number of shoots were formed by both, the induction of resident and extra-axillary meristem and from the cut surface of the segments. The results are in conformity with similar earlier findings in Lycaste aromatica where the basal sections proved optimal for producing more number of plantlets and regeneration from apical segments was via activation of apical meristem (Mata-Rosas et al. 2010). The shoots rooted in the same medium composition while still attached to the donor explants in all the cultures.

Therefore, from this study it is concluded that initiation of regeneration response is directly related to the juvenility of the responding tissue and growth stimulus to which they are subjected. Among apical and basal segments, basal segments regenerate more shoots. NAA alone or with BA should be used to initiate, multiply and maintain the healthy pseudobulbous plantlets. This simple one step protocol has the potential to mass propagate and conserve this rare orchid of medicinal and ornamental importance. Further focus of the current study is on acclimatization of in vitro raised cultures of $C$. flaccida and restoring them back in their natural habitat. Thus the simple protocol devised here will certainly contribute to the mass propagation and conservation of $C$. flaccida. 


\section{References}

Arditti J and Ernst R (1993) Micropropagation of orchids. John Wiley, New York.

Basker S and Narmatha VB (2006) Micropropagation of Coelogyne stricta (D. Don) Schltr. via pseudobulb segment culture. Trop. Subtrop. Agrosys. 6: 31-35.

Benson EE (2000) Special symposium: In vitro plant recalcitrance. Do free radicals have a role in plant tissue culture recalcitrance? In vitro Cell. Dev. Biol. Plant. 36: 163-170.

CITES (2012) Convention on International Trade in Endangered Species of Wild Fauna and Flora CITES (2012) Appendices I, II and III. http://www.cites.org

Cousson A and Tran Thanh Van K (1993) Influence of ionic composition of the culture medium on de novo flower formation in tobacco thin cell layers. Can. J. Bot. 71: 506511.

Decruse SW, Gangaprasad A, Seeni S and Menon SV (2003) Micropropagation and ecorestoration of Vanda spathulata, an exquisite orchid. Plant Cell Tiss. Organ Cult. 72:199-202.

George ES (1993) Plant Propagation by Tissue Culture. Exegetics, England.

George PS and Ravishankar GA (1997) In vitro multiplication of Vanilla planifolia using axillary bud explants. Plant Cell Rep. 16: 490-494.

Hong PI, Chen JT and Chang WC (2010) Shoot development and plant regeneration from protocorm-like bodies of Zygopetalum mackayi. In vitro Cell. Dev. Biol. Plant. 46: 306-311.

Janarthanam B and Seshadri S (2008) Plantlet regeneration from leaf derived callus of Vanilla planifolia Andr. In vitro Cell. Dev. Biol. Plant. 44: 84-89.

Kanjilal B, Sarker D DE, Mitra J and Datta KB (1999) Stem disc culture: Development of a rapid mass propagation method for Dendrobium moschatum (Buch.-Ham.) Swartz An endangered orchid. Current Sci. 77: 497-500.

Kaur Saranjeet and Bhutani KK (2010) Micropropagation of Malaxis acuminata D. Don: A rare orchid of high therapeutic value. Open Acc. J. Med. Arom. Plants. 1: 29-33.

Majumdar PL and Maiti DC (1989) Flaccidin and oxaloflaccidin, two phenenthrene derivatives of the orchid Coelogyne flaccida. Phytochem. 28: 887-890.

Martin KP (2007) Micropropagation of the bamboo orchid Arundina graminifolia (D. Don) Hochr. through protocorm-like bodies using node explants. Propagation Orna. Plants 7: $97-100$.

Mata-Rosas M, Baltazar-Garcia RJ, Moon P, Heitz P and Luna-Monterrojo VE (2010) In vitro regeneration of Lycaste aromatic (Graham ex Hook.) Lindl. (Orchidaceae) from pseudobulb sections. Plant Biotechnol. Rep. 4: 157-163.

Medina RD, Flachland E A, Gonzalez AM, Terada G, Faloci MM and Mroginski LA (2009) In vitro tuberization and plant regeneration from multi-nodal segment culture of Habenaria bractescens Lindl., an argentenian wetland orchid. Plant Cell Tiss. Organ Cult. 97: 91-101.

Misra AK and Bhatnagar SP (1995) Direct shoot regeneration from leaf explants of cucumber (Cucumis sativus L.). Phytomorp. 45: 47-55. 
Mitra GC, Prasad RN and Chowdhury AR (1976) Inorganic salts and differentiation of protocorms in seed callus of an orchid and correlated changes in its free amino acid content. Indian J. Expt. Biol. 14: 350-351.

Morel GM (1960) Producing virus free cymbidiums. Amer. Orchid Soc. Bull. 29: 495-497.

Morel GM (1970) Neues auf dem Gebiet der meristem (in german). For Die Orchidee 21: 435-443.

Pant B and Thapa D (2012) In vitro mass propagation of an epiphytic orchid, Dendrobium primulinum Lindl. through shoot tip culture. African J. Biotechnol. 11: 9970-9974.

Pinto G, Silva S, Park YS, Neves L, Araujo C and Santos C (2008) Factors influencing somatic embryogenesis induction in Eucalyptus globulus Labill.: Basal medium and anti-browning agents. Plant Cell Tiss. Organ Cult. 95: 79-88.

Pyakurel D and Gurung K (2008) Uses of orchids. In: Enumeration of orchids and estimation of current stock of traded orchids in Rolpa district. A report submitted to district forest office, Rolpa, Nepal. pp. 6-28.

Pyati AN, Murthy HN, Hahn EJ and Paek KY (2002) In vitro propagation of Dendrobium macrostachyum Lindl.- A threatened orchid. Indian J. Exp. Biol. 40: 620-623.

Rajkarnikar KM (2011) Propagation of Cymbidium aloifolium (L.) Sw. in vitro by seeds. Bull. Dept. Plant Res., Thapathali, Kathmandu, Nepal 33: 27-30.

Ramage CM and Williams RR (2002) Mineral nutrition and plant morphogenesis. In vitro Cell. Dev. Biol. Plant. 38: 116-124.

Shiau YJ, Nalwade SM, Hsia CN, Mulabogal U and Tsay HS (2005) In vitro propagation of the Chinese medicinal plant, Dendrobium candidum Wall. Ex. Lindl., from axenic nodal segments. In vitro Cell. Dev. Biol. Plant. 41: 666-670.

Shimasaki K and Uemoto S (1987) Studies on micropropagation of Japanese Calanthe species. Sci. Bull. Fac. Agri., Kyunshu University 42: 293-297.

Stewart SL and Button J (1976) Tissue culture studies in Paphiopedilum. In: Proceedings of Eighth World Orchid Conference, Frankfurt, The Netherlands. pp. 372-378.

Sungkum L and Deb CR (2009) Regeneration competence of Tainia latifolia (Lindl.) Benth ex Hook. pseudobulb segments: An in vitro study. Indian J. Biotechnol. 8: 121-126.

Sunitibala H and Kishor R (2009) Micropropagation of Dendrobium transparens L. from axenic pseudobulb segments. Indian J. Biotechnol. 8: 448-452.

Terzi M and Lo Schiavo (1990) Somatic embryogenesis. In: Development in crop Science, Plant Tissue Culture: Application and Limitations, Bhojwani SS (Ed.), Elsevier, Amsterdam, Oxford, New York, Tokyo. pp. 115-151.

Vajrabhaya M (1978) Tissue culture of dormant buds from Cattleya back bulbs. Orchid Rev. 86: 256-257.

Vij SP and Kaur Saranjeet (1998) Micropropagation of therapeutically important orchids : Malaxis acuminata. J. Orchid Soc. India (TOSI). 12: 89-93. 